\title{
Genetic merit for fertility traits in Holstein cows: VI. Oocyte developmental competence and embryo development
}

\author{
S. G. Moore, ${ }^{1 *}$ S. B. Cummins, ${ }^{1,2 *}$ S. Mamo, ${ }^{2}$ P. Lonergan, ${ }^{2}$ T. Fair, ${ }^{2}$ and S. T. Butler ${ }^{1} \dagger$ \\ ${ }_{1}^{1}$ Animal and Grassland Research and Innovation Centre, Teagasc, Moorepark, Fermoy, Co. Cork, Ireland P61 P302 \\ ${ }^{2}$ School of Agriculture and Food Science, University College Dublin, Belfield, Dublin 4, Ireland D04 N2E5
}

\begin{abstract}
The hypothesis of this study was that cows with good genetic merit for fertility traits (Fert+) would produce oocytes and embryos of greater quality than cows with poor genetic merit for fertility traits (Fert-) and that mRNA expression of candidate genes would reflect the observed differences in quality. The aim of the study, therefore, was to determine the effect of genetic merit for fertility traits on morphological classification and mRNA abundance of key genes in immature oocytes and cumulus cells following ovum pick-up and in embryos following superovulation, artificial insemination (AI), and uterine flushing. In experiment 1, 17 Fert+ and 11 Fert- cows, ranging from 54 to $84 \mathrm{~d}$ in milk, were submitted to ovum pick-up on 4 occasions during a 2 -wk period. Recovered cumulus-oocyte complexes (COC) were morphologically graded. Oocytes and cumulus cells were separated, and mRNA abundance of genes associated with oocyte developmental competence was measured. There was no effect of genotype on the distribution of COC grades or on the mRNA abundance of the candidate genes in grade $1 \mathrm{COC}$. In experiment 2, 20 Fert+ and 19 Fert- cows, ranging from 71 to 189 $\mathrm{d}$ in milk, were submitted to superovulation and AI. The uteri of cows that responded to the superovulation protocol (17 Fert+ and 16 Fert- cows) were nonsurgically flushed $7 \mathrm{~d}$ postovulation. Recovered embryos were morphologically graded, and mRNA abundance of genes associated with embryo development was measured in grade 1 blastocysts. The response to the superovulation protocol was assessed by counting the number of codominant follicles on the day of AI, which was similar for both genotypes $(22.0 \pm 9.7$ and $19.8 \pm$ 8.2 for Fert+ and Fert- cows, respectively). There was no effect of genotype on the proportion of transferable
\end{abstract}

Received October 9, 2018.

Accepted January 10, 2019.

*These authors contributed equally to this work.

†Corresponding author: stephen.butler@teagasc.ie embryos recovered or on the mRNA abundance of the candidate genes tested in the grade 1 blastocysts. Of the total embryos classified as blastocysts, however, the Fert+ cows tended to have a greater proportion of grade 1 blastocysts compared with Fert- cows (90\% vs. $64 \%$, respectively). In conclusion, genetic merit for fertility traits had a no effect on mRNA abundance of the candidate genes that were examined in immature oocytes and cumulus cells and in embryos recovered after superovulation. The observed differences in morphological blastocyst quality following superovulation would suggest that the superior reproductive performance of Fert+ cows could arise during the later stages of embryo development from d 7 until maternal recognition of pregnancy.

Key words: gene expression, reproduction, ovum pickup, superovulation

\section{INTRODUCTION}

Intense genetic selection for milk production without regard to fertility traits results in a substantial increase in dairy cow milk yield but at the expense of reproductive performance (Berry et al., 2014; Rearte et al., 2018). The physiological rationale for this negative association is that the hormonal and metabolic adaptations necessary for the initiation and maintenance of lactation are antagonistic to optimal reproductive performance, potentially through mechanisms impinging on oocyte competence and embryo development (Lucy, 2001).

Pregnancy establishment requires a series of finely orchestrated physiological events. Preovulatory oocyte growth and maturation, mediated by cumulus cells, are central to this process. Maternally derived proteins and mRNA transcripts stored during oocyte growth are the main modulators of embryo development until embryonic genome activation (Fair et al., 2007). After fertilization of the oocyte, the resulting embryo undergoes the first mitotic cleavage divisions (Lonergan et al., 2016). The 8- to 16-cell stage coincides with a period of major genome activation (Sirard, 2012), and 
subsequent progression of the embryo to the morula and blastocyst stages involves a massive temporal increase in the number of expressed genes (Graf et al., 2014). By d 7 after fertilization, the blastocyst consists of an inner cell mass and the trophectoderm (Lonergan et al., 2016).

The timing of fertility failure can be examined by flushing uteri at set time intervals post-AI. Approximately 20 to $50 \%$ of pregnancy losses occur within the first $7 \mathrm{~d}$ after AI, $30 \%$ occur during d 8 to 28 , and $12 \%$ occur during d 29 to 60 (Wiltbank et al., 2016). Uterine flushing also facilitates assessment of embryo quality by morphological assessment (Lindner and Wright, 1983), which has a significant effect on subsequent pregnancy rates (Hasler et al., 1987). Transcriptome analyses have also revealed differentially expressed genes between healthy and compromised oocytes and embryos (ElSayed et al., 2006; Huang and Khatib, 2010; SalilewWondim et al., 2010; Biase et al., 2014) independent of morphological assessment.

Many in vitro models and animal models of high and low fertility are established to determine characteristics of fertilization rate and embryo quality that contribute to poor fertility in lactating dairy cows (Sartori et al., 2002; Leroy et al., 2005, 2006; de Feu et al., 2008; Van Hoeck et al., 2011). Also, Snijders et al. (2000) reported greater in vitro blastocyst development using oocytes from cows with average compared with high genetic merit for milk production and high compared with low BCS. Conversely, blastocyst development following oocyte recovery by ovum pick-up (OPU), in vitro fertilization, and culture was similar in cows and heifers with divergent metabolic states (Rizos et al., 2005; Matoba et al., 2012). These studies provided a valuable insight into the effects of lactation and physiological concentrations of fatty acids, BHB, and glucose on characteristics of oocyte and embryo quality, but they were limited due to the constraints of in vitro culture or were confounded by the effects of age, energy status, and BCS.

We established and validated a lactating Holstein cow genetic model of fertility that has overcome the limitations of previously mentioned models and used this animal model to identify some of the effects of genetic merit for fertility traits on phenotypic measures of fertility (Cummins et al., 2012a). Compared with cows with poor genetic merit for fertility traits (Fert-), cows with good genetic merit for fertility traits (Fert+) have reduced incidence of clinical and subclinical endometritis (Moore et al., 2014a), stronger expression of estrus (Cummins et al., 2012b), greater luteal phase progesterone (P4) concentrations (Cummins et al., 2012b; Moore et al., 2014b), and better coordination of corpus luteum (CL) and endometrium gene expression to support luteal $\mathrm{P} 4$ synthesis and endometrial receptivity (Moore et al., 2016). The hypothesis was that Fert+ cows would produce oocytes and embryos of greater quality than Fert- cows and that mRNA expression of candidate genes would reflect the observed differences in quality. The study determined the effects of genetic merit for fertility traits on morphological classification and transcript abundance of key genes in immature oocytes and cumulus cells following OPU and in embryos following superovulation, $\mathrm{AI}$, and uterine flushing.

\section{MATERIALS AND METHODS}

\section{Herd Establishment}

A genetic model of fertility was established in Teagasc Moorepark (Fermoy, Ireland) to elucidate the mechanisms responsible for poor fertility in lactating Holstein dairy cows (Cummins et al., 2012a). Using the official dairy evaluation published by ICBF (2007), the national dairy cattle database was screened for heifers due to calve for the first time in spring 2008. Restrictions were placed on the EBV for milk production (between +200 and $+900 \mathrm{~kg}$ ) and proportion of Holstein genetics $(>75 \%)$. Within this population, heifers with extreme positive (i.e., poor fertility) and negative (i.e., good fertility) EBV for calving interval were identified. Poor-fertility (Fert-) heifers were restricted to animals for which both the sire and the maternal grandsire had positive EBV for calving interval. Conversely, goodfertility (Fert+) heifers were restricted to animals for which both the sire and the maternal grandsire had negative EBV for calving interval. Heifers identified as being available for purchase were screened for infectious diseases, purchased, and moved in January 2008 to Teagasc Moorepark. Seventeen Fert+ cows and 16 Fert- cows were enrolled in the current study, and their EBV are presented in Table 1.

\section{Management System}

The physical characteristics and performance of the cows enrolled was reported previously (Cummins et al., 2012a). For the 2-wk duration of the OPU experiment, 17 Fert+ and 11 Fert- cows, ranging from 54 to 84 d postpartum, were managed in a typical grass-based spring-calving production system. Following parturition, cows were turned out to grass in early February, grazed under a rotational grazing system, and milked twice daily. The mean daily herbage allowance was 14.3 $\pm 1.29 \mathrm{~kg}$ of $\mathrm{DM} / \mathrm{d}$ per cow and was supplemented with $4.0 \pm 1.69 \mathrm{~kg}$ of concentrate /d per cow. The OPU procedure took place after morning milking and took 
Table 1. The mean $\mathrm{EBV}^{1}$ (SD in parentheses) for the 2 groups of Holstein cows $^{2}$ studied based on their milk production, individual calving interval, sire calving interval, and maternal grandsire calving interval $^{3,4}$

\begin{tabular}{lcc}
\hline Genotype & Fert+ & Fert- \\
\hline NAHF $^{5}(\%)$ & $91(6.0)$ & $93(6.2)$ \\
Milk $(\mathrm{kg})$ & $+462(133.4)$ & $+478(145.2)$ \\
Fat $(\mathrm{kg})$ & $+22(7.3)$ & $+17(6.9)$ \\
Protein $(\mathrm{kg})$ & $+18.8(5.5)$ & $+17.8(6.1)$ \\
Fat $(\mathrm{g} / \mathrm{kg})$ & $+0.088(0.1)$ & $-0.016(0.1)$ \\
Protein $(\mathrm{g} / \mathrm{kg})$ & $+0.072(0.05)$ & $+0.042(0.1)$ \\
Survival $(\%)$ & $+3.2(0.8)$ & $-0.2(1.2)$ \\
Calving interval $(\mathrm{d})$ & $-6.36(1.4)$ & $+5.86(2.9)$ \\
Sire calving interval $(\mathrm{d})$ & $-9.06(3.6)$ & $+7.3(3.0)$ \\
Maternal grandsire & $-5.44(2.5)$ & $+7.92(5.0)$ \\
$\quad$ calving interval (d) & & \\
\hline
\end{tabular}

${ }^{1}$ All PTA were obtained from ICBF (2007) and multiplied by 2 to convert to EBV.

${ }^{2}$ Fert $-=$ cows with poor genetic merit for fertility traits; Fert $+=$ cows with good genetic merit for fertility traits.

${ }^{3}$ There were 7 and 5 first-lactation cows in the Fert- and Fert+ groups, respectively. There were 8 and 12 second-lactation cows in the Fert - and Fert+ groups, respectively.

${ }^{4} 85 \%$ of the cows enrolled in experiment 2 were also enrolled in experiment 1.

${ }^{5}$ Proportion of North-American Holstein Friesian ancestry.

no longer than 30 min per cow, after which cows were returned to fresh pasture.

For the duration of the superovulation experiment, cows were kept on a woodchip pad, given full-time access to a TMR diet, and milked twice daily. The diet composition on a DM per cow basis was grass silage ( 5 $\mathrm{kg}$ of DM), maize silage ( $5 \mathrm{~kg}$ of DM), straw $(2.2 \mathrm{~kg}$ of $\mathrm{DM})$, and concentrate $(5.25 \mathrm{~kg}$ of $\mathrm{DM})$. The concentrate composition on a fresh weight basis (relative proportion in parentheses) was soybean meal (30\%), citrus pulp (25\%), wheat (25\%), maize gluten (10\%), molasses $(5 \%)$, flax seed $(2 \%)$, and minerals and vitamins $(3 \%)$. The average ( \pm SD) chemical composition of the TMR was $135.0 \pm 25.3 \mathrm{~g}$ of $\mathrm{CP} / \mathrm{kg}$ of $\mathrm{DM}, 484.2$ $\pm 12.6 \mathrm{~g}$ of $\mathrm{NDF} / \mathrm{kg}$ of $\mathrm{DM}, 323.2 \pm 12.1 \mathrm{~g}$ of $\mathrm{ADF} / \mathrm{kg}$ of DM, and $67.9 \pm 6.0 \mathrm{~g}$ of $\mathrm{ash} / \mathrm{kg}$ of DM.

\section{Experiment 1: Oocyte Developmental Competence Following OPU}

Transvaginal OPU was performed twice weekly for 2 wk (i.e., 4 sessions per animal; Figure 1). An Esaote Pie medical scanner with a mechanical multiangle OPU probe (Pie Medical Equipment B.V., Maastricht, the Netherlands) was used to aspirate cumulus-oocyte complexes (COC) as described by Bols et al. (1995). Briefly, animals were sedated with xylazine (1 mg i.v. $/ 100 \mathrm{~kg}$ of BW), and caudal epidural anesthesia was induced using $4 \mathrm{~mL}$ of $2 \%$ lidocaine to prevent abdominal straining. The contents of the rectum were emptied and the vulva and perineal area were thoroughly cleaned. The OPU probe was inserted into the anterior vagina. The ovaries were manipulated per the rectum and positioned over the transducer face. A disposable 19-gauge hypodermic needle was extended through the vaginal wall and then through the ovary until the needle could be visualized puncturing the follicle wall. Aspiration was performed using a foot-operated suction pump at $40 \mathrm{mmHg}$. The follicular aspirate was collected in a 50-mL conical tube containing $10 \mathrm{~mL}$ of PBS with heparin $(400 \mathrm{IU} / \mathrm{mL})$ and $\mathrm{BSA}(3 \mathrm{mg} / \mathrm{mL})$ maintained at $37^{\circ} \mathrm{C}$ in a heated block.

Following collection, the aspirate was taken to the laboratory and passed through a 44- $\mu \mathrm{m}$ embryo filter (Miniflush, Minitub, Germany). The filter was rinsed with $50 \mathrm{~mL}$ of PBS containing heparin $(400 \mathrm{IU} / \mathrm{mL}$ )

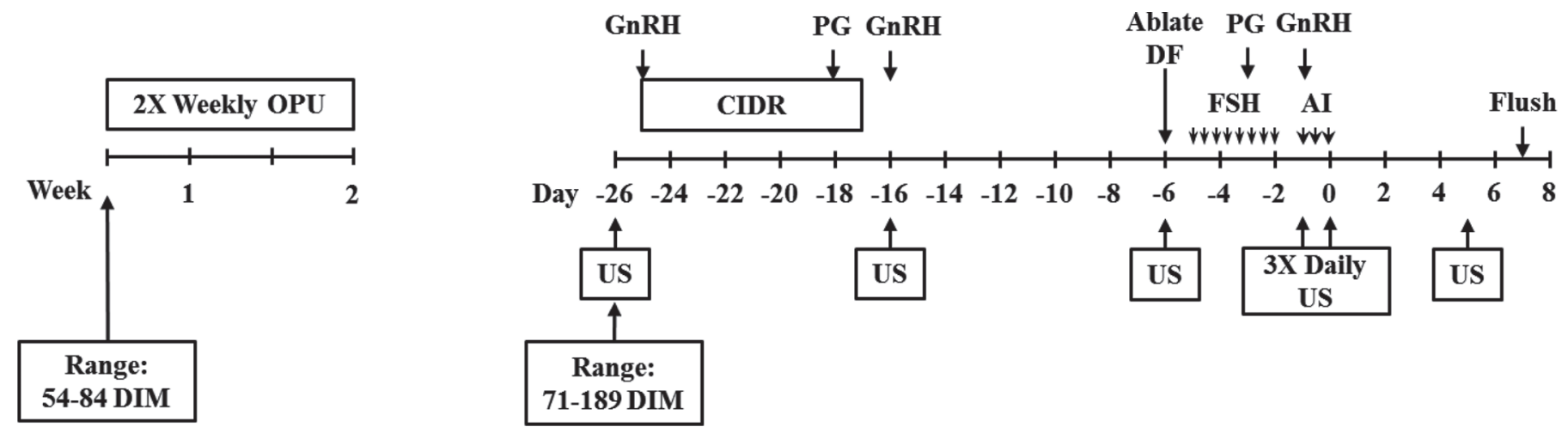

Figure 1. Schematic diagram summarizing the ovum pick-up (left panel) and superovulation (right panel) protocols. Left: Ovum pick-up (OPU) was performed twice weekly for $2 \mathrm{wk}$ beginning at 54 to 84 DIM. Cows grazed perennial ryegrass swards during this experimental period. Right: The superovulation protocol began at 71 to 189 DIM. Day 0 was designated as the day when the first ovulation occurred following FSH treatment. Cows were fed a TMR diet and housed on a woodchip pad during the experimental period. US $=$ ultrasound; CIDR $=$ intravaginal progesterone-releasing device containing $1.38 \mathrm{~g}$ of progesterone; $\mathrm{GnRH}=\mathrm{GnRH}$ agonist injections contained $10 \mu \mathrm{g}$ of buserelin; $\mathrm{PG}=\mathrm{PGF}{ }_{2 \alpha}$ analog; DF = dominant follicle. 
and BSA $(3 \mathrm{mg} / \mathrm{mL})$ to free any objects lodged in the filter membrane, and the remaining liquid above the filter was poured into a searching dish. With the use of a stereomicroscope, COC were isolated and graded in accordance with de Loos et al. (1989) as follows. Grade 1 COC had a compact, multilayered cumulus investment and homogeneous ooplasm, and were light and transparent. Grade 2 COC had a compact, multilayered cumulus investment and homogeneous ooplasm but with a coarse appearance and a darker zone at the periphery of the oocyte; the total COC was slightly darker and less transparent. Grade 3 COC had a less compact cumulus investment, the ooplasm was irregular with dark clusters, and the total COC was darker than grades 1 and 2. Grade 4 oocytes had an expanded cumulus investment; the cumulus cells were scattered in dark clumps in a jelly matrix, the ooplasm was irregular with dark clusters, and the total COC was dark and irregular. Grades 1 and 2 were classified as goodquality oocytes, and grades 3 and 4 were classified as poor-quality oocytes. Once COC were graded, oocytes were then stripped of cumulus cells by repeated pipetting, washed twice in PBS, and snap frozen in liquid nitrogen until further analysis. The corresponding cumulus cells were also labeled and snap frozen in liquid nitrogen until further analysis.

\section{Experiment 2: Embryo Development Following Superovulation}

Synchronization of Ovulation and Superovulation Protocol. Transrectal ultrasonography was carried out on all cows to determine utero-ovarian status (7.5-MHz transrectal transducer; Aloka SSD-900, Aloka Ltd., Tokyo, Japan). Cows that were diagnosed as having a uterine infection were removed from the study (4 cows). The remaining 20 Fert+ and 19 Fert- cows that were between 71 and 189 DIM were enrolled on a 32-d superovulation protocol, staggered over $4 \mathrm{~d}$, with an even number of Fert+ and Fert- cows ( 5 Fert+ and 5 Fert-) enrolled on each day with the exception of the fourth day ( 5 Fert+ and 4 Fert-).

The superovulation protocol used is illustrated in Figure 1 (d 0 is designated the day of first ovulation following the superovulation protocol). Briefly, on d -25 each cow was administered an i.m. GnRH agonist injection containing $10 \mu \mathrm{g}$ of buserelin (Receptal; Intervet Ireland, Dublin, Ireland), and a controlled internal drug release device containing $1.38 \mathrm{~g}$ of $\mathrm{P} 4$ was inserted per vaginum (CIDR; Pfizer Ireland, Dublin, Ireland). On d -18 , each cow was administered an i.m. $\mathrm{PGF}_{2 \alpha}$ injection containing $25 \mathrm{mg}$ of dinoprost tromethamine (Lutalyse; Pfizer Ireland). The drug release devices were removed on $\mathrm{d}-17$. On $\mathrm{d}-16$, cows were scanned for the presence of a dominant follicle and administered an i.m. GnRH agonist injection containing $10 \mu \mathrm{g}$ of buserelin (Receptal). On d -6, ultrasonography was carried out to detect the presence of an early to mid luteal phase CL; cows that had failed to develop a CL were removed from the study (2 Fert+ and 2 Fertcows). Dominant follicles present on either ovary were physically ablated at the time of examination. Commencing on d -5 , FSH (Folltropin, Bioniche Animal Health Europe Ltd., Clonee, Co. Meath, Ireland) was administered i.m. at 12 -h intervals in decreasing doses over a 4 -d period $(280,210,140$, and $70 \mathrm{IU} / \mathrm{d}$ for d 1 , 2,3 , and 4 , respectively). Each cow was administered an i.m. $\mathrm{PGF}_{2 \alpha}$ injection to coincide with the sixth injection of FSH.

Following behavioral estrus, cows were administered an i.m. GnRH agonist injection, and scanning took place at 8-h intervals to determine the number of preovulatory dominant follicles and the time of ovulation. All cows were inseminated with frozen-thawed semen collected from a single ejaculate of a Holstein-Friesian bull, and sperm viability and quality were verified before use. The level of coancestry between the bull used for insemination and the cows on the study was examined over 6 generations. The average coancestry coefficient was $0.4 \%$ for both genotypes, with the maximum for any 1 cow being $0.5 \%$. Inseminations took place 8 , 16 , and $24 \mathrm{~h}$ after the final GnRH injection; cows that failed to ovulate the dominant follicle within $24 \mathrm{~h}$ of the final GnRH injection received an additional insemination at $32 \mathrm{~h}$ after $\mathrm{GnRH}$ administration. One cow from each genotype failed to ovulate after the GnRH injection, and both were removed from the study. A final ovarian scan of the remaining 17 Fert+ and 16 Fert- cows took place on d 5 after first ovulation to determine the number of CL on each ovary.

Embryo Recovery. Uteri were flushed on d 7 after first ovulation by an experienced technician using standard nonsurgical techniques. Caudal epidural anesthesia was induced using $4 \mathrm{~mL}$ of $2 \%$ lidocaine to prevent abdominal straining. Both uterine horns were flushed with $500 \mathrm{~mL}$ of sterile PBS. The resulting lavage was passed through a 44- $\mu \mathrm{m}$ embryo filter (Miniflush, Minitub, Germany). The filter was carefully rinsed 3 times with PBS to ensure removal of all structures. The resulting fluid was poured into a searching dish and was examined for embryos and oocytes under a stereomicroscope. The recovered structures were then morphologically graded according to criteria of the International Embryo Technology Society (Wright, 1998) by an experienced embryologist blind to the genotype of the donor cow, as follows. Grade 1 embryos had a symmetrical and spherical mass with individual blastomeres that were uniform in size, color, and density; irregularities 
were minor; and at least $85 \%$ of the cellular material was an intact, viable embryonic mass. Grade 2 embryos had moderate irregularities in the overall shape of the embryonic mass or in size, color, and density of individual cells and at least $50 \%$ of the embryonic mass was intact. Grade 3 embryos had major irregularities in the shape of the embryonic mass or in size, color, and density of individual cells and at least $25 \%$ of the embryo mass was intact. Grade 4 embryos were dead or degenerating.

Blood Sampling. Circulating estradiol (E2) and FSH concentrations were measured in samples collected on the day of first AI, and concentrations of P4 in plasma were determined in samples collected on the day of the flush. Blood samples were collected via coccygeal venipuncture into Vacutainers containing lithium heparin as an anticoagulant (Becton Dickinson, Plymouth, UK). Samples were immediately centrifuged at $1,500 \times g$ for $15 \mathrm{~min}$ at $5^{\circ} \mathrm{C}$; plasma was decanted and stored at $-20^{\circ} \mathrm{C}$ until further analysis. Circulating E2 concentrations were determined by RIA following an extraction step (Prendiville et al., 1995) using an Adaltis MAIA E2 Kit (Biostat, Stockport, UK). The intra-assay coefficient of variation was $12.1 \%$. Circulating FSH concentrations were quantified using a validated RIA as described by Crowe et al. (1997). The intra-assay coefficient of variation was $17 \%$. Circulating $\mathrm{P} 4$ concentrations were determined using a commercially available solid-phase RIA (Coat-A-Count Progesterone, Diagnostic Products Corp., Los Angeles, CA). The intra-assay coefficient of variation was $8 \%$.

\section{RNA Extraction, cDNA Synthesis, and qPCR of Oocyte, Cumulus, and Blastocyst Samples}

Messenger RNA was extracted from individual samples of oocytes and cumulus cells ( $\mathrm{n}=8$ per genotype) that originated from $\mathrm{COC}$ that were morphologically graded as grade 1 and were from growing follicles that were no more than $4 \mathrm{~d}$ old (i.e., no samples were used from the first round of OPU as age of follicle was unknown). Messenger RNA was extracted from pools of 2 blastocysts per cow (Fert+: $\mathrm{n}=4$, Fert-: $\mathrm{n}=5$ ) that were graded as grade 1 . The protocols for mRNA extraction from oocytes, cumulus, and blastocysts were similar except that TRI Reagent (Sigma-Aldrich Ireland Ltd., Dublin, Ireland) was used for total RNA extraction from oocytes and cumulus, whereas lysis/ binding buffer (Dynal; Invitrogen, Paisley, UK) was used for total RNA extraction from blastocysts. For all samples, mRNA was subsequently isolated using Dynabeads mRNA Direct Micro Kit (Invitrogen) following the manufacturer's instructions. Synthesis of cDNA was carried out in a $20-\mu \mathrm{L}$ reaction volume using
SuperScript III reverse transcriptase kit (Invitrogen) supplemented with $200 \mathrm{ng}$ of random primers (Invitrogen) and stored at $-20^{\circ} \mathrm{C}$. The reaction conditions were $75^{\circ} \mathrm{C}$ for $5 \mathrm{~min}, 25^{\circ} \mathrm{C}$ for $5 \mathrm{~min}, 50^{\circ} \mathrm{C}$ for $60 \mathrm{~min}$, and $75^{\circ} \mathrm{C}$ for $15 \mathrm{~min}$ to inactivate the enzyme.

A panel of candidate genes associated with oocyte and blastocyst developmental competence in bovine and murine species was collated from O'Shea et al. (2012) and Mamo et al. (2011a,b), respectively (Supplemental Table S1; https://doi.org/10.3168/jds.2018-15813). Genes specifically associated with lipid metabolism (STAR and PTEN), cellular development (TMSB10 and BMP4), apoptosis and proliferation (MED1 and IGFBP3), cell cycle (HMGA1, KIF23, and CDC123), and DNA repair $(A T R X)$ were tested on oocyte samples. Genes specifically associated with apoptosis (BAG3), DNA repair (AVEN and $A T R X)$, stress response (HSP90B1), actin nucleation (WASL), transcription (EGR1), inflammatory response (PTX3), prostaglandin synthesis (PTGS2), extracellular matrix $(V C A N)$, and hyaluronic acid synthesis (HAS2) were tested on cumulus samples. The gene PPIA was measured in all oocyte and cumulus samples as the reference gene (Mamo et al., 2011a). Genes specifically associated with formation of tight junctions (TJP2), transcription (EGR1), cell adhesion (CDH1), prostaglandin synthesis (PTGS2), chromosome stability (PTTG1), and apoptosis (DAD1) were tested on blastocyst samples. The genes HPRT1 and EEF1E1 were measured in all blastocyst samples as the reference genes (Mamo et al., 2007). Bovine sequences to design primers for the examined genes were retrieved from the National Center for Biotechnology Information (http://www.ncbi.nlm.nih.gov/) database and used to design primers. Primers for quantitative real-time PCR (qPCR; Supplemental Table S1; https: //doi.org/10.3168/jds.2018-15813) were designed using the Primer3 software program (Rozen and Skaletsky, 2000) and were commercially synthesized (Eurofins MWG Operon, Ebersberg, Germany).

The relative abundance of the examined genes was assessed by performing qPCR using the ABI Prism 7700 Sequence Detection System (Applied Biosystems, Foster City, CA). The qPCR reactions were carried out using Power SYBR Green master mix (Applied Biosystems), and the reaction conditions were $50^{\circ} \mathrm{C}$ for $2 \mathrm{~min}, 95^{\circ} \mathrm{C}$ for $10 \mathrm{~min}, 45$ cycles of $15 \mathrm{~s}$ at $95^{\circ} \mathrm{C}$ and $60^{\circ} \mathrm{C}$ for $1 \mathrm{~min}$ for annealing and extension. Samples were measured in duplicate for all genes. After each qPCR reaction, specificity of amplicons was confirmed by melt curve analysis, and fragment sizes were confirmed by agarose gel electrophoresis. The reference genes were stably expressed across all samples. Relative gene expression (calibrated, normalized relative quantity) values were determined using the qbase ${ }^{+}$software package (http: 
//www.qbaseplus.com; Biogazelle, Ghent, Belgium). Results are reported relative to the level of expression in Fert + cows to calculate a fold-change value.

\section{Statistical Analysis}

All statistical analyses and data handling were carried out using SAS (SAS Institute Inc., Cary, NC). Data were checked for normality and homogeneity of variance. Data that were not normally distributed were log-transformed or raised to the power of lambda. A Box-Cox transformation analysis was used to obtain the appropriate lambda value and normalize the distribution. The effect of genotype on circulating concentrations of E2 and FSH on the day of first AI and $\mathrm{P} 4$ on the day of uterine flush were determined using mixed models with cow nested within genotype as a random effect. The effects of genotype, parity, and the interaction between genotype and parity were tested; calving date, number of dominant follicles (for E2 and FSH analysis), and number of CL (for P4 analysis) were included as adjustment variables; and effects with $P$-value $<0.1$ were maintained in the final model.

For each cow, only COC collected from the second, third, and fourth rounds of OPU were retained for analysis. The proportion of good-quality oocytes (grades 1 and 2), the proportion of poor-quality oocytes (grades 3 and 4), and the proportion of oocytes of each individual grade were calculated. The effect of genotype on the proportion of oocytes within a particular grade was analyzed using 1-way nonparametric test with Wilcoxon score (PROC NPAR1WAY).

For each cow, the proportion of good-quality embryos (grade 1 and 2 morulas and blastocysts), the proportion of nontransferable structures (poor-quality morulas and blastocysts, degenerate embryos, unfertilized oocytes, and empty zonas), and the proportion of embryos of each individual grade were calculated. The effect of genotype on the proportion of embryos with a particular grade was analyzed using a 1-way nonparametric test with Wilcoxon score.

The effect of genotype on the mRNA abundance of the candidate genes was determined using mixed models with cow nested within genotype as a random effect. The effects of genotype, parity, and the interaction between genotype and parity were tested, calving date was included as an adjustment variable, and effects with a $P$-value $<0.1$ were maintained in the final model. The false discovery rate was controlled by applying the Benjamini-Hochberg procedure with the false discovery rate set at $10 \%$ to the statistical analysis of each sample type (Benjamini and Hochberg, 1995).

\section{RESULTS}

\section{COC Morphological Classification and mRNA Abundance}

As a proportion of follicles aspirated, the recovery rate of COC was similar in both genotypes (60 and $63 \%$ for Fert+ and Fert-cows, respectively; Table 2). There was no effect $(P>0.05)$ of genotype on the proportion of good-quality COC or on the proportion of each specific grade of good-quality COC (Table 2). Both genotypes had a similar proportion of poor-quality COC; however, the Fert- cows tended $(P=0.076)$ to have a greater proportion of grade 4 structures (Table 2). There was no effect of genotype on mRNA abundance of the candidate genes tested in the oocytes and cumulus cells after controlling the false discovery rate using the Benjamini-Hochberg procedure (Figure 2).

\section{Ovarian Structures and Circulating Steroid Concentration After Superovulation}

The response of both genotypes to the superovulation protocol, as measured by the number of dominant follicles on the day of $\mathrm{AI}$ and the number of CL on d 5 post-AI, was similar $(22.0 \pm 9.7$ and $16.8 \pm 5.3$, respectively, for Fert+ cows and $19.8 \pm 8.2$ and $16.8 \pm$ 5.4, respectively, for Fert- cows; Table 3). No differences $(P>0.05)$ between genotypes were observed in circulating concentrations of E2 and FSH on the day of AI (Table 3). Circulating P4 concentrations tended $(P=0.079)$ to be greater in Fert + cows on the day of embryo recovery compared with Fert- cows (Table 3 ).

\section{Embryo Morphological Classification and mRNA Abundance}

Based on the number of CL on d 5 post-AI, the recovery rate of embryos was 70 and $60 \%$ for the Fert+ and Fert- cows, respectively. There was no effect $(P$ $>0.05$ ) of genotype on the proportion of embryos recovered that were graded as transferable. Of the total embryos classified as blastocysts, however, the Fert+ cows tended $(P=0.054)$ to have a greater proportion of grade 1 blastocysts compared with Fert- cows (90 vs. $64 \%$, respectively). There was no effect of genotype on the proportion of nontransferable structures recovered or on the proportion of each specific grade of nontransferable structure $(P>0.05)$. There was no effect of genotype on mRNA abundance of the candidate genes tested in the grade 1 blastocysts after controlling the false discovery rate using the Benjamini-Hochberg procedure (Figure 2). 
Table 2. The effect of genetic merit for fertility traits on morphological quality of immature oocytes following ovum pick-up

\begin{tabular}{|c|c|c|c|}
\hline \multirow[b]{2}{*}{ Variable } & \multicolumn{2}{|c|}{ Genotype $^{1}$} & \multirow[b]{2}{*}{$P$-value } \\
\hline & Fert+ & Fert- & \\
\hline No. of cows & 17 & 11 & \\
\hline Average DIM (SD) & $72(12)$ & $61(9)$ & \\
\hline No. of follicles aspirated & 244 & 245 & \\
\hline No. of cumulus-oocyte complexes recovered & 147 & 155 & \\
\hline Recovery rate $^{2}$ & 0.60 & 0.63 & \\
\hline Proportion of good-quality oocytes (total no.) & $0.85(117)$ & $0.80(121)$ & 0.42 \\
\hline Grade 1 oocytes $^{3}$ & $0.43(58)$ & $0.5(62)$ & 0.43 \\
\hline 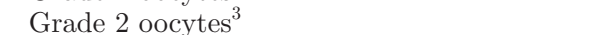 & $0.57(59)$ & $0.5(59)$ & 0.43 \\
\hline Proportion of poor-quality oocytes (total no.) & $0.14(30)$ & $0.20(34)$ & 0.42 \\
\hline Grade 3 oocytes ${ }^{4}$ & $0.92(27)$ & $0.69(22)$ & 0.076 \\
\hline Grade 4 oocytes $^{4}$ & $0.08(3)$ & $0.31(12)$ & 0.076 \\
\hline
\end{tabular}

\section{DISCUSSION}

The aim of this study was to determine the effects of genetic merit for fertility traits on morphological classification and transcript abundance of key genes in immature oocytes and cumulus cells following OPU and in embryos following superovulation, AI, and uterine flushing. The current study indicates that the inferior fertility performance of the Fert- cows was not a result of an inferior pool of immature oocytes based on morphological classification following OPU. Messenger RNA abundance of the examined genes in grade 1 oocytes and their associated cumulus cells were not different between genotypes. Similarly, morphological quality of embryos and mRNA abundance of the candidate genes on $\mathrm{d} 7$ following superovulation were not markedly different between genotypes. However, Fert+ cows did have a greater proportion of grade 1 blastocysts, potentially indicating that divergence in embryo quality between genotypes could occur during the later stages of embryo development.

The COC enables the transfer of essential compounds between cumulus cells and the oocyte via transzonal projections and gap junctions (Albertini et al., 2001; Macaulay et al., 2016). It is during antral follicular development that the oocyte acquires the molecular competence required for embryo development and oocyte quality has been reported to be the main factor affecting blastocyst yield (Lonergan et al., 1994; Rizos et al., 2002). A report by Snijders et al. (2000) examining cows of high and medium genetic merit for milk production suggested that reproductive failure in cows with high genetic merit for milk production was at least partially a result of poorer oocyte quality. Moreover, oocyte quality was independent of phenotypic milk yield, highlighting the effect of genetic merit for milk production per se on oocyte developmental competence. In the current study, the lack of an association between genetic merit for fertility traits and oocyte morphological quality would suggest that oocyte developmental competence could have a stronger association with genetic merit for milk production than fertility traits.

Genetic merit for fertility traits did not alter the proportion of transferable d 7 embryos (morula and blastocyst) recovered following superovulation in the current study. This is in contrast with a previous report by de Feu et al. (2008), who compared cows with different genetic merit for fertility and milk production traits (New Zealand Holstein-Friesian vs. North American Holstein-Friesian). The finding that New Zealand Holstein-Friesian cows had a greater proportion of transferable embryos could, however, have been influenced by a difference in daily milk yield between the strains that was not observed in Fert+ and Fertcows (Cummins et al., 2012a) used in the current study. The effect of New Zealand ancestry on the proportion of grade 1 blastocysts (de Feu et al., 2008) was consistent with the current study; both Fert+ cows and New Zealand Holstein-Friesian cows had more high-quality embryos at a more advanced stage of development on d 7. These subtle differences suggest that the effect of genetic merit for fertility traits on embryo development could manifest in processes controlling the later stages of embryo survival such as uterine environment (Leroy et al., 2008) and maternal recognition of pregnancy (Lonergan, 2010). In support of this argument, we have reported downregulation of endometrial genes involved in $\mathrm{PGF}_{2 \alpha}$ synthesis and inflammation and an 

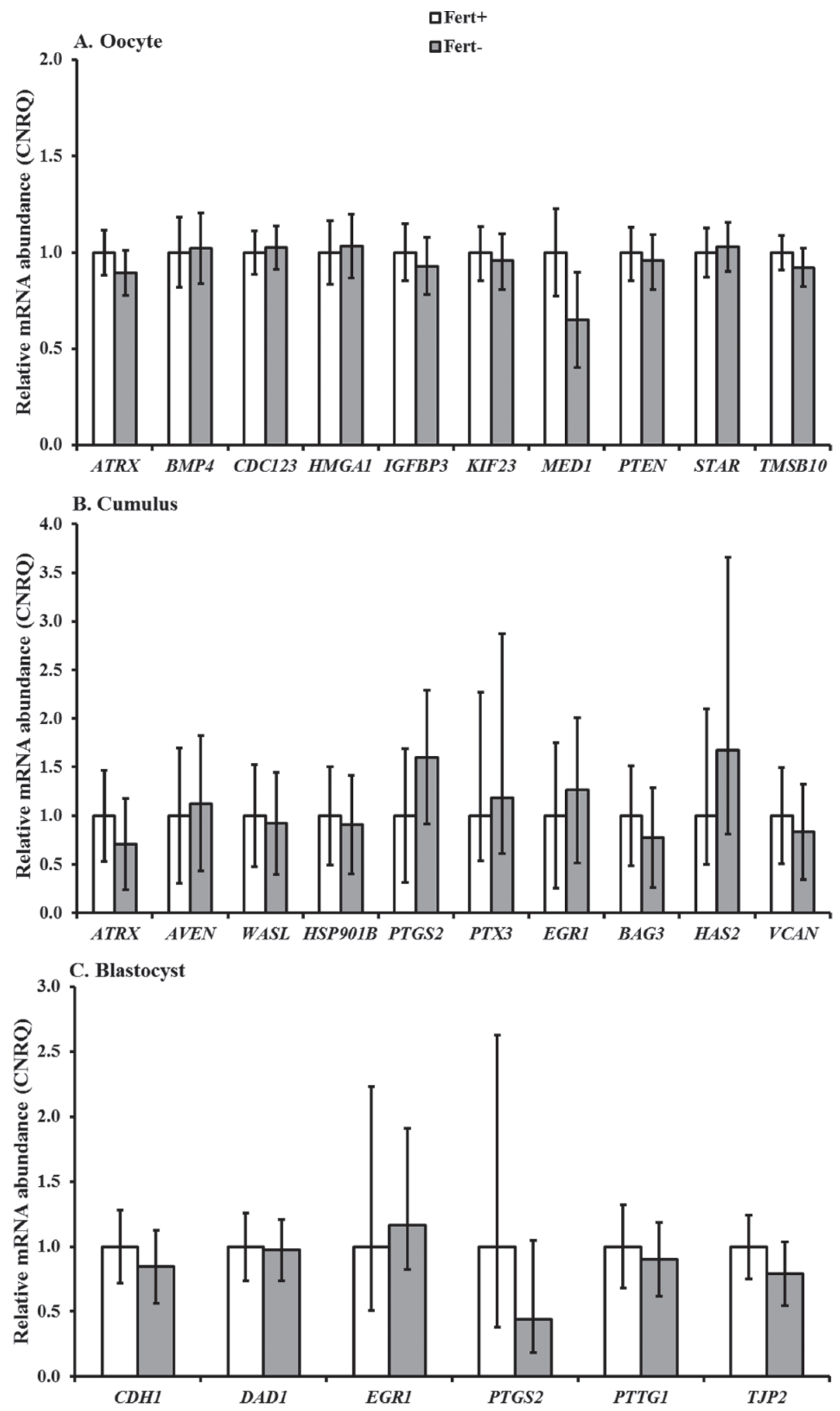

Figure 2. Relative abundance of mRNA in oocytes (A), cumulus cells (B), and blastocysts (C) in cows with good genetic merit for fertility traits (Fert+) and cows with poor genetic merit for fertility traits (Fert-). All expression levels are relative to the level of expression in Fert+ oocytes, cumulus cells, and blastocysts, which was arbitrarily set to 1 . Vertical bars indicate $95 \%$ CI. Cumulus-oocyte complexes (n $=8$ per genotype) and blastocysts ( $\mathrm{n}=2$ per pool; Fert+: $\mathrm{n}=4$ pools; Fert-: $\mathrm{n}=5$ pools) scored as grade 1 were retained for analysis of mRNA abundance. No genotype, parity, or genotype $\times$ parity interaction effects were detected for the mRNA abundance of any genes measured $(P>$ $0.05) . \mathrm{CNRQ}=$ calibrated, normalized relative quantity. 
upregulation of endometrial genes involved in ion transport, gated-voltage channels, and cytoskeletal genes in Fert+ cows on d 7 and 13 of the estrous cycle that may support embryo development and maintenance of pregnancy (Moore et al., 2016; Moran et al., 2017).

Previous studies that carried out transcriptional profiling of bovine oocytes and embryos have identified variation in the abundance of mRNA encoding key genes that may subsequently affect embryo development (Fair et al., 2007; Kues et al., 2008; Katz-Jaffe et al., 2009; Salilew-Wondim et al., 2010; Graf et al., 2014). The lack of association between genetic merit for fertility traits and the mRNA abundance of the selected candidate gene markers of oocyte and cumulus cell quality would suggest that developmental competence of immature oocytes may not be the limiting factor in the fertility performance of Fert- cows. In support of this argument, Matoba et al. (2012) reported that there was no evidence for an effect of metabolic status on oocyte quality as assessed by in vitro fertilization. It is possible that the influence of the oocyte on fertility differences between the Fert+ and Fert- cows is mediated during the final stages of oocyte maturation (processes occurring after the luteinizing hormone surge) as reported by Rizos et al. (2002). Future studies of oocyte quality in dairy cow fertility models should be directed toward mature (after luteinizing hormone surge) oocytes.
In the current study, the response of cows to the superovulation protocol, as determined by the number of codominant follicles on both ovaries at the time of $\mathrm{AI}$, and the recovery rate of ova and embryo structures exceeded values previously reported in lactating dairy cows (Leroy et al., 2005; Chebel et al., 2008; de Feu et al., 2008). The reason for this favorable animal response to the superovulation protocol is not clear; however, differences in plane of nutrition or superovulation protocol used could play a part. High superovulatory responses have been associated with decreased embryo viability as a result of increased circulating E2 concentrations and consequently increased oviductal insulin-like growth factor 1 concentrations (Beker et al., 2002; Velazquez et al., 2009). The high superovulatory response in the current study could therefore partially explain the relatively high proportion of nontransferable embryos recovered from both genotypes and the absence of an effect of genetic merit for fertility traits on the proportion of transferable embryos.

Circulating P4 concentrations have been shown to play a pivotal role in embryo survival by regulating the maternal immunoresponse to the fetus (Hansen, 1998; Arck et al., 2007) and influencing oviductal and uterine environment (Mann and Lamming, 2001; Sreenan et al., 2001; Green et al., 2005). A delayed increase in P4 as early as d 4 to 7 is associated with an adverse effect on

Table 3. The effect of genetic merit for fertility traits on embryo recovery, quality, and stage of development on d 7 post-AI

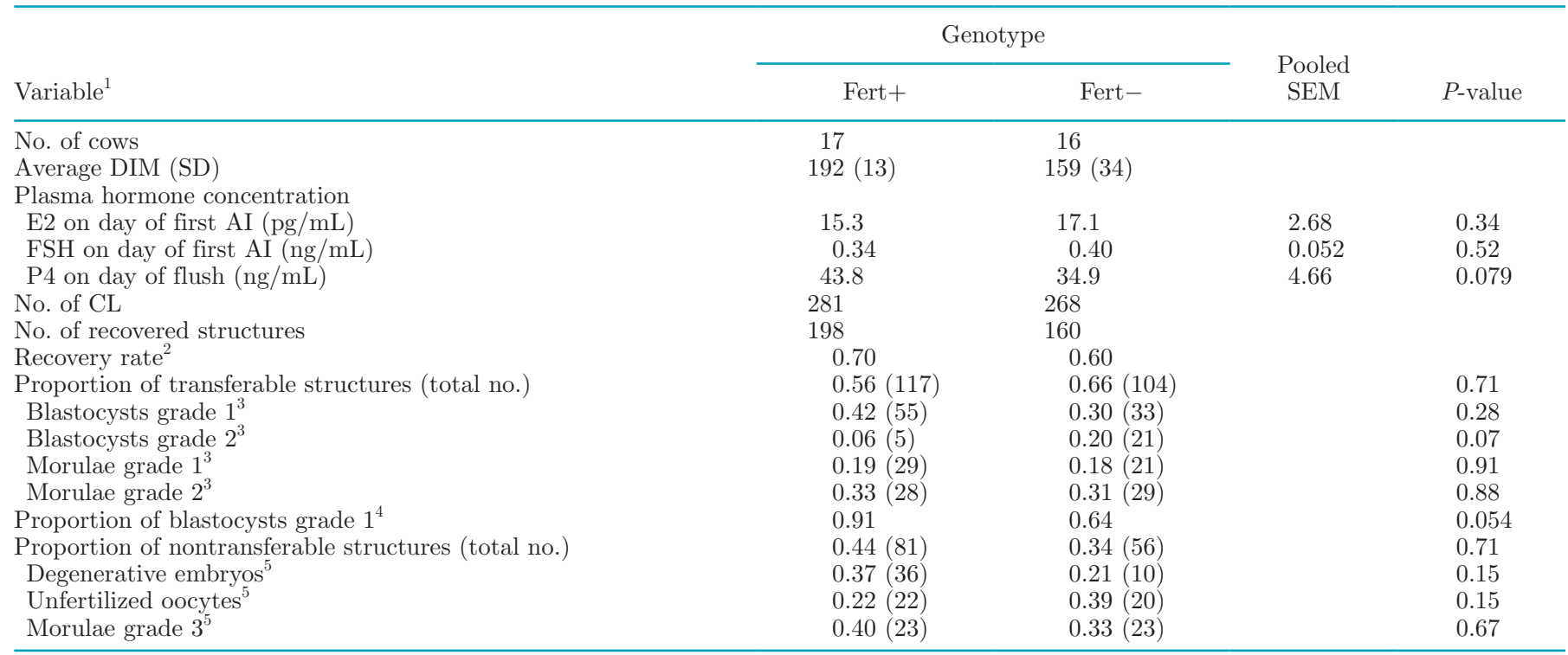

${ }^{1} \mathrm{E} 2=$ estradiol; $\mathrm{P} 4=$ progesterone; $\mathrm{CL}=$ corpus luteum.

${ }^{2}$ Number of recovered structures/number of CL.

${ }^{3}$ As a proportion of transferable embryos.

${ }^{4}$ As a proportion of blastocysts.

${ }^{5}$ As a proportion of nontransferable embryos. 
the likelihood of pregnancy (Diskin and Morris, 2008). In the current study, superovulation led to the formation of multiple CL (on average $>16 \mathrm{CL}$ ) and circulating $\mathrm{P} 4$ concentrations approximately 6 times greater than normal biological concentrations. As previously reported in Cummins et al. (2012b) and Moore et al. (2014b), the superior reproductive performance of the Fert+ cows was partially attributed to them having 25 to $80 \%$ greater circulating $\mathrm{P} 4$ concentrations following a single ovulation. In the current study, superphysiological circulating $\mathrm{P} 4$ concentrations due to the presence of multiple CL are known to affect endometrial physiology (Forde et al., 2012) and could potentially have compensated for any inherent deficiency in circulating P4 concentrations that would have arisen in Fert- cows with a single CL, thus potentially altering uterine environment and embryo survival.

\section{CONCLUSIONS}

Results of the current study suggest that the previously reported inferior reproductive performance of Fert- cows was not a result of differences in oocyte developmental competence, based on immature COC morphological quality, or mRNA abundance of the examined markers of oocyte developmental quality in grade 1 oocytes and corresponding cumulus cells. Moreover, the observed differences in blastocyst quality following superovulation would suggest that the superior reproductive performance of Fert+ cows could arise during the later stages of embryo development from $\mathrm{d} 7$ until maternal recognition of pregnancy.

\section{ACKNOWLEDGMENTS}

We thank J. P. Murphy and the farm staff at Teagasc Moorepark (Fermoy, Co. Cork, Ireland) for management and care of the animals. We also thank J. Quinn (Genexcel Irl Ltd., Co. Cork, Ireland) for his technical assistance. Funding from National Development Plan and Dairy Levy (Ireland) is gratefully acknowledged.

\section{REFERENCES}

Albertini, D. F., C. Combelles, E. Benecchi, and M. Carabatsos. 2001. Cellular basis for paracrine regulation of ovarian follicle development. Reproduction 121:647-653.

Arck, P., P. J. Hansen, B. Mulac Jericevic, M.-P. Piccinni, and J. Szekeres-Bartho. 2007. Progesterone during pregnancy: Endocrineimmune cross talk in mammalian species and the role of stress. Am. J. Reprod. Immunol. 58:268-279.

Beker, A. R. C. L., B. Colenbrander, and M. M. Bevers. 2002. Effect of $17 \beta$-estradiol on the in vitro maturation of bovine oocytes. Theriogenology 58:1663-1673.

Benjamini, Y., and Y. Hochberg. 1995. Controlling the false discovery rate: A practical and powerful approach to multiple testing. J. R. Stat. Soc. B 57:289-300.
Berry, D. P., E. Wall, and J. E. Pryce. 2014. Genetics and genomics of reproductive performance in dairy and beef cattle. Animal 8(Suppl. 1):105-121.

Biase, F. H., R. E. Everts, R. Oliveira, W. K. F. Santos-Biase, G. K. Fonseca Merighe, L. C. Smith, L. Martelli, H. Lewin, and F. V. Meirelles. 2014. Messenger RNAs in metaphase II oocytes correlate with successful embryo development to the blastocyst stage. Zygote 22:69-79.

Bols, P. E. J., J. M. M. Vandenheede, A. Van Soom, and A. de Kruif. 1995. Transvaginal ovum pick-up (OPU) in the cow: A new disposable needle guidance system. Theriogenology 43:677-687.

Chebel, R. C., D. G. B. Demétrio, and J. Metzger. 2008. Factors affecting success of embryo collection and transfer in large dairy herds. Theriogenology 69:98-106.

Crowe, M. A., V. Padmanabhan, N. Hynes, S. J. Sunderland, W. J. Enright, I. Z. Beitins, and J. F. Roche. 1997. Validation of a sensitive radioimmunoassay to measure serum follicle-stimulating hormone in cattle: Correlation with biological activity. Anim. Reprod. Sci. 48:123-136.

Cummins, S. B., P. Lonergan, A. C. O. Evans, D. P. Berry, R. D. Evans, and S. T. Butler. 2012a. Genetic merit for fertility traits in Holstein cows: I. Production characteristics and reproductive efficiency in a pasture-based system. J. Dairy Sci. 95:1310-1322.

Cummins, S. B., P. Lonergan, A. C. O. Evans, and S. T. Butler. 2012b. Genetic merit for fertility traits in Holstein cows: II. Ovarian follicular and corpus luteum dynamics, reproductive hormones, and estrus behavior. J. Dairy Sci. 95:3698-3710.

de Feu, M. A., J. Patton, A. C. O. Evans, P. Lonergan, and S. T. Butler. 2008. The effect of strain of Holstein-Friesian cow on size of ovarian structures, periovulatory circulating steroid concentrations, and embryo quality following superovulation. Theriogenology 70:1101-1110.

de Loos, F., C. van Vliet, P. van Maurik, and T. Kruip. 1989. Morphology of immature bovine oocytes. Gamete Res. 24:197-204.

Diskin, M. G., and D. Morris. 2008. Embryonic and early foetal losses in cattle and other ruminants. Reprod. Domest. Anim. 43(Suppl. 2):260-267.

El-Sayed, A., M. Hoelker, F. Rings, D. Salilew, D. Jennen, E. Tholen, M.-A. Sirard, K. Schellander, and D. Tesfaye. 2006. Large-scale transcriptional analysis of bovine embryo biopsies in relation to pregnancy success after transfer to recipients. Physiol. Genomics 28:84-96.

Fair, T., F. Carter, S. Park, A. C. O. Evans, and P. Lonergan. 2007. Global gene expression analysis during bovine oocyte in vitro maturation. Theriogenology 68:S91-S97.

Forde, N., F. Carter, S. D. Francesco, J. P. Mehta, M. Garcia-Herreros, A. Gad, D. Tesfaye, M. Hoelker, K. Schellander, and P. Lonergan. 2012. Endometrial response of beef heifers on day 7 following insemination to supraphysiological concentrations of progesterone associated with superovulation. Physiol. Genomics 44:1107-1115.

Graf, A., S. Krebs, V. Zakhartchenko, B. Schwalb, H. Blum, and E. Wolf. 2014. Fine mapping of genome activation in bovine embryos by RNA sequencing. Proc. Natl. Acad. Sci. USA 111:4139-4144.

Green, M. P., M. G. Hunter, and G. E. Mann. 2005. Relationships between maternal hormone secretion and embryo development on day 5 of pregnancy in dairy cows. Anim. Reprod. Sci. 88:179-189.

Hansen, P. J. 1998. Regulation of uterine immune function by progesterone-Lessons from the sheep. J. Reprod. Immunol. 40:63-79.

Hasler, J. F., A. D. McCauley, W. F. Lathrop, and R. H. Foote. 1987 Effect of donor-embryo-recipient interactions on pregnancy rate in a large-scale bovine embryo transfer program. Theriogenology 27:139-168

Huang, W., and H. Khatib. 2010. Comparison of transcriptomic landscapes of bovine embryos using RNA-Seq. BMC Genomics 11:711.

ICBF (Irish Cattle Breeding Federation). 2007. Autumn 2007 Official Dairy Evaluation. ICBF, Bandon, Co. Cork, Ireland.

Katz-Jaffe, M. G., B. R. McCallie, K. A. Preis, J. Filipovits, and D. K. Gardner. 2009. Transcriptome analysis of in vivo and in vitro matured bovine MII oocytes. Theriogenology 71:939-946.

Kues, W. A., S. Sudheer, D. Herrmann, J. W. Carnwath, V. Havlicek, U. Besenfelder, H. Lehrach, J. Adjaye, and H. Niemann. 2008. 
Genome-wide expression profiling reveals distinct clusters of transcriptional regulation during bovine preimplantation development in vivo. Proc. Natl. Acad. Sci. USA 105:19768-19773.

Leroy, J. L., G. Opsomer, A. Van Soom, I. Goovaerts, and P. Bols. 2008. Reduced fertility in high-yielding dairy cows: Are the oocyte and embryo in danger? Part I. The importance of negative energy balance and altered corpus luteum function to the reduction of oocyte and embryo quality in high-yielding dairy cows. Reprod. Domest. Anim. 43:612-622.

Leroy, J. L., T. Vanholder, G. Opsomer, A. Van Soom, and A. Kruif. 2006. The in vitro development of bovine oocytes after maturation in glucose and $\beta$-hydroxybutyrate concentrations associated with negative energy balance in dairy cows. Reprod. Domest. Anim. 41:119-123.

Leroy, J. L. M. R., G. Opsomer, S. De Vliegher, T. Vanholder, L. Goossens, A. Geldhof, P. E. J. Bols, A. de Kruif, and A. Van Soom. 2005. Comparison of embryo quality in high-yielding dairy cows, in dairy heifers and in beef cows. Theriogenology 64:2022-2036.

Lindner, G. M., and R. W. Wright. 1983. Bovine embryo morphology and evaluation. Theriogenology 20:407-416.

Lonergan, P. 2010. Using basic approaches to address applied problems in dairy reproduction. Soc. Reprod. Fertil. Suppl. 67:377-386.

Lonergan, P., T. Fair, N. Forde, and D. Rizos. 2016. Embryo development in cattle. Theriogenology 86:270-277.

Lonergan, P., P. Monaghan, D. Rizos, M. P. Boland, and I. Gordon. 1994. Effect of follicle size on bovine oocyte quality and developmental competence following maturation, fertilization, and culture in vitro. Mol. Reprod. Dev. 37:48-53.

Lucy, M. C. 2001. Reproductive loss in high-producing dairy cattle: Where will it end? J. Dairy Sci. 84:1277-1293.

Macaulay, A. D., I. Gilbert, S. Scantland, E. Fournier, F. Ashkar, A. Bastien, H. A. S. Saadi, D. Gagné, M.-A. Sirard, É. W. Khandjian, F. J. Richard, P. Hyttel, and C. Robert. 2016. Cumulus cell transcripts transit to the bovine oocyte in preparation for maturation. Biol. Reprod. 94:16.

Mamo, S., F. Carter, P. Lonergan, C. L. Leal, A. Al Naib, P. McGettigan, J. P. Mehta, A. C. Evans, and T. Fair. 2011a. Sequential analysis of global gene expression profiles in immature and in vitro matured bovine oocytes: Potential molecular markers of oocyte maturation. BMC Genomics 12:151.

Mamo, S., A. B. Gal, S. Bodo, and A. Dinnyes. 2007. Quantitative evaluation and selection of reference genes in mouse oocytes and embryos cultured in vivo and in vitro. BMC Dev. Biol. 7:14.

Mamo, S., J. P. Mehta, P. McGettigan, T. Fair, T. E. Spencer, F. W. Bazer, and P. Lonergan. 2011b. RNA sequencing reveals novel gene clusters in bovine conceptuses associated with maternal recognition of pregnancy and implantation. Biol. Reprod. 85:1143-1151.

Mann, G. E., and G. Lamming. 2001. Relationship between maternal endocrine environment, early embryo development and inhibition of the luteolytic mechanism in cows. Reproduction 121:175-180.

Matoba, S., L. O'Hara, F. Carter, A. K. Kelly, T. Fair, D. Rizos, and P. Lonergan. 2012. The association between metabolic parameters and oocyte quality early and late postpartum in Holstein dairy cows. J. Dairy Sci. 95:1257-1266.

Moore, S. G., T. Fair, P. Lonergan, and S. T. Butler. 2014a. Genetic merit for fertility traits in Holstein cows: IV. Transition period, uterine health, and resumption of cyclicity. J. Dairy Sci. 97:27402752 .

Moore, S. G., J. E. Pryce, B. J. Hayes, A. J. Chamberlain, K. E. Kemper, D. P. Berry, M. McCabe, P. Cormican, P. Lonergan, T. Fair, and S. T. Butler. 2016. Differentially expressed genes in endometrium and corpus luteum of Holstein cows selected for high and low fertility are enriched for sequence variants associated with fertility. Biol. Reprod. 94:19.

Moore, S. G., S. Scully, J. A. Browne, T. Fair, and S. T. Butler. 2014b. Genetic merit for fertility traits in Holstein cows: V. Fac- tors affecting circulating progesterone concentrations. J. Dairy Sci. 97:5543-5557.

Moran, B., S. T. Butler, S. G. Moore, D. E. MacHugh, and C. J. Creevey. 2017. Differential gene expression in the endometrium reveals cytoskeletal and immunological genes in lactating dairy cows genetically divergent for fertility traits. Reprod. Fertil. Dev. $29: 274-282$.

O'Shea, L. C., J. Mehta, P. Lonergan, C. Hensey, and T. Fair. 2012. Developmental competence in oocytes and cumulus cells: Candidate genes and networks. Syst Biol Reprod Med 58:88-101.

Prendiville, D. J., W. Enright, M. Crowe, L. Vaughan, and J. Roche. 1995. Immunization of heifers against gonadotropin-releasing hormone: Antibody titers, ovarian function, body growth, and carcass characteristics. J. Anim. Sci. 73:2382-2389.

Rearte, R., S. J. LeBlanc, S. G. Corva, R. L. de la Sota, I. M. LacauMengido, and M. J. Giuliodori. 2018. Effect of milk production on reproductive performance in dairy herds. J. Dairy Sci. 101:75757584 .

Rizos, D., L. Burke, P. Duffy, M. Wade, J. F. Mee, K. J. O'Farrell, M. MacSiurtain, M. P. Boland, and P. Lonergan. 2005. Comparisons between nulliparous heifers and cows as oocyte donors for embryo production in vitro. Theriogenology 63:939-949.

Rizos, D., F. Ward, P. Duffy, M. P. Boland, and P. Lonergan. 2002. Consequences of bovine oocyte maturation, fertilization or early embryo development in vitro versus in vivo: Implications for blastocyst yield and blastocyst quality. Mol. Reprod. Dev. 61:234-248.

Rozen, S., and H. Skaletsky. 2000. Primer3 on the WWW for general users and for biologist programmers. Pages 365-386 in Methods in Molecular Biology. Vol. 132. S. Misener and S. Krawetz, ed. Humana Press, Totowa, NJ.

Salilew-Wondim, D., M. Hölker, F. Rings, N. Ghanem, M. Ulas-Cinar, J. Peippo, E. Tholen, C. Looft, K. Schellander, and D. Tesfaye. 2010. Bovine pretransfer endometrium and embryo transcriptome fingerprints as predictors of pregnancy success after embryo transfer. Physiol. Genomics 42:201-218.

Sartori, R., R. Sartor-Bergfelt, S. A. Mertens, J. N. Guenther, J. J. Parrish, and M. C. Wiltbank. 2002. Fertilization and early embryonic development in heifers and lactating cows in summer and lactating and dry cows in winter. J. Dairy Sci. 85:2803-2812.

Sirard, M.-A. 2012. Factors affecting oocyte and embryo transcriptomes. Reprod. Domest. Anim. 47(Suppl. 4):148-155.

Snijders, S. E. M., P. Dillon, D. O'Callaghan, and M. P. Boland. 2000. Effect of genetic merit, milk yield, body condition and lactation number on in vitro oocyte development in dairy cows. Theriogenology 53:981-989.

Sreenan, J. M., M. G. Diskin, and D. G. Morris. 2001. Embryo survival rate in cattle: A major limitation to the achievement of high fertility. BSAP Occasional Publ. 26:93-104.

Van Hoeck, V., R. G. Sturmey, P. Bermejo-Alvarez, D. Rizos, A. Gutierrez-Adan, H. J. Leese, P. E. J. Bols, and J. L. M. R. Leroy. 2011. Elevated non-esterified fatty acid concentrations during bovine oocyte maturation compromise early embryo physiology. PLoS One 6:e23183

Velazquez, M. A., J. Zaraza, A. Oropeza, R. Webb, and H. Niemann. 2009. The role of IGF1 in the in vivo production of bovine embryos from superovulated donors. Reproduction 137:161-180.

Wiltbank, M. C., G. M. Baez, A. Garcia-Guerra, M. Z. Toledo, P. L. J. Monteiro, L. F. Melo, J. C. Ochoa, J. E. P. Santos, and R. Sartori. 2016. Pivotal periods for pregnancy loss during the first trimester of gestation in lactating dairy cows. Theriogenology 86:239-253.

Wright, J. 1998. Photographic illustrations of embryo developmental stage and quality codes. Pages 167-170 in Manual of the International Embryo Transfer Society. 3rd ed. International Embryo Technology Society, Savoy, IL. 